NASA

Technical

Paper

2047

1982

\section{Effect of Shot Peening on Surface Fatigue Life of Carburized and Hardened AISI 9310 Spur Gears}

Dennis P. Townsend and Erwin V. Zaretsky

Lewis Research Center

Cleveland, Ohio 


\section{Summary}

Gear surface fatigue endurance tests were condu zted on two groups of 10 gears each of carburized and hardened AISI 9310 spur gears manufactured from the same heat of material. Both groups were manufactured with standard ground tooth surfaces. The second group was subjected to an additional shot-peening proces:i on the gear tooth surfaces and root radius to produre a residual surface compressive stress. The gear fitch diameter was $8.89 \mathrm{~cm}(3.5 \mathrm{in}$.$) . Test conditions were a$ gear temperature of $350 \mathrm{~K}\left(170^{\circ} \mathrm{F}\right)$, a maximum Hertz stress of $1.71 \times 10^{9} \mathrm{~N} / \mathrm{m}^{2}(248000 \mathrm{psi})$, and a speed of $10000 \mathrm{rpm}$.

The shot-peened gears exhibited pitting fatigue lives 1.6 times the life of the standard gears without shot peening. Residual stress measurements and ana ysis indicate that the longer fatigue life is the result of the higher compressive stress produced by the shot peening. The life for the shot-peened gear was calculated to $b \in 1.5$ times that for the plain gear by using the measured residual stress difference for the standard and shotpeened gears. The measured residual stress for the shotpeened gears was much higher than that for the stanclard gears.

\section{Introduction}

Shot peening has long been used as a method for improving the bending strength of gear teeth (ref;. 1 to 3). However, shot peening has not been considered as a means of extending the surface fatigue life of gears. In essence, shot peening induces a residual compressive stress below the surface of the gear tooth. Studie; of residual stresses in rolling-element bearings have shiswn that increased residual compressive stress will incr zase rolling-element (surface) fatigue life (refs. 4 and 5). There is always a need to improve the surface fatigue lif: of aircraft gears, especially in helicopter and V/STOL aircraft.

The objectives of the research reported herein wer: (1) to investigate the effects of shot peening of gear teeth on the surface fatigue life of standard ground, casecarburized, and hardened AISI 9310 spur gears, (2) to compare the life of shot-peened gears to that of non-s notpeened gears manufactured with the same material and specifications, and (3) to determine the residual stress produced by shot peening and its effect on the surface fatigue life.

To accomplish these objectives, 20 spur gears vere manufactured from a consumable-electrode-vacuummelted single heat of AISI 9310 material. Ten of tiese gears were shot peened after finish grinding. The zear pitch diameter was $8.89 \mathrm{~cm}$ (3.5 in.). Both the shot- peened and non-shot-peened gears were then tested to fatigue by surface pitting under identical test conditions. These test conditions included a gear temperature of $350 \mathrm{~K}\left(170^{\circ} \mathrm{F}\right)$, a maximum Hertz stress of $1.71 \times 10^{9}$ $\mathrm{N} / \mathrm{m}^{2}(248000 \mathrm{psi})$, and a speed of $10000 \mathrm{rpm}$.

\section{Apparatus, Specimens, and Procedure}

\section{Gear Test Apparatus}

The gear fatigue tests were performed in the NASA Lewis Research Center's gear test apparatus (fig. 1). This test rig uses the four-square principle of applying the test gear load so that the input drive only needs to overcome the frictional losses in the system.

A schematic of the test rig is shown in figure 1(b). Oil pressure and leakage flow are supplied to the load vanes through a shaft seal. As the oil pressure is increased on the load vanes inside the slave gear, torque is applied to the shaft. This torque is transmitted through the test gears back to the slave gear, where an equal but opposite torque is maintained by the oil pressure. This torque on the test gears, which depends on the hydraulic pressure

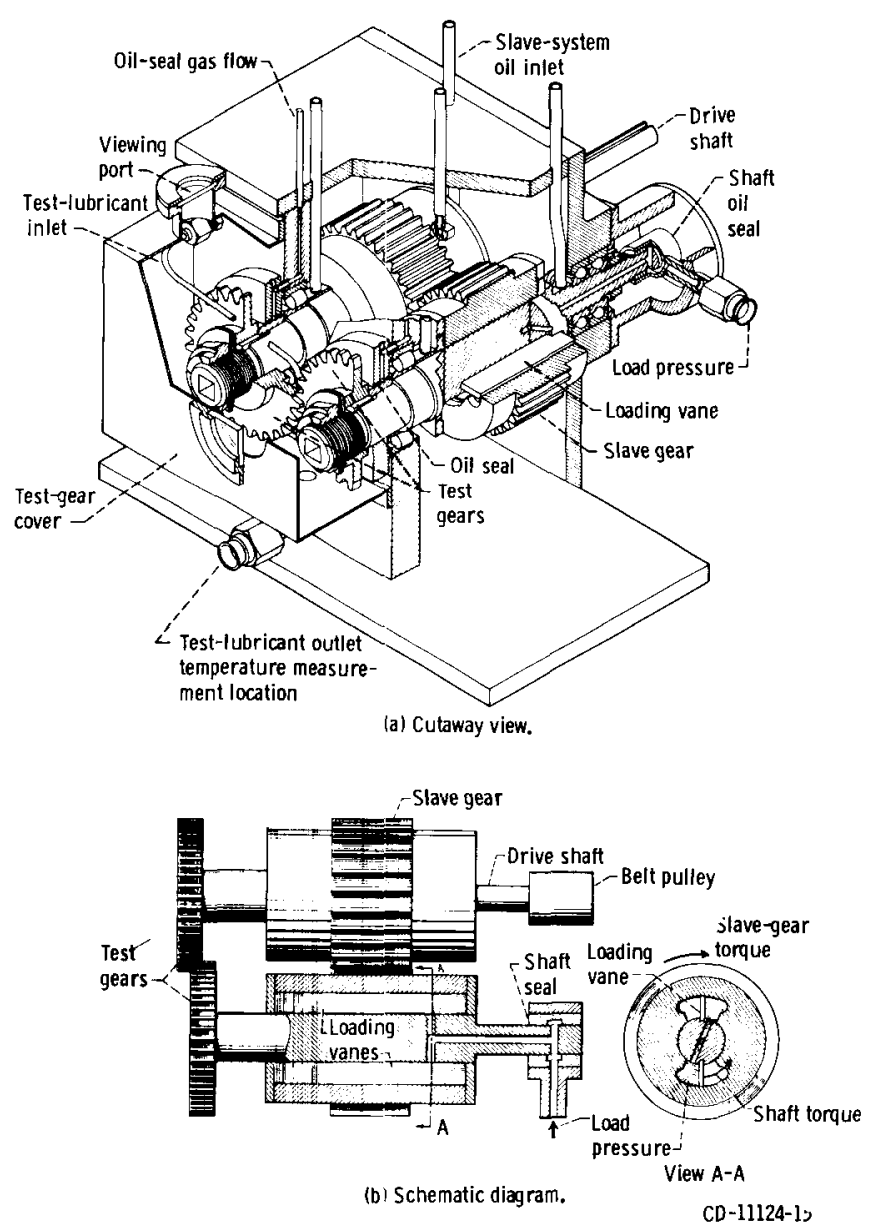

Figure 1. - NASA Lewis Research Center's gear fatigue test apparatus. 
applied to the load vanes, loads the gear teeth to the desired stress level. The two identical test gears can be started under no load, and the load can be applied gradually, without changing the running track on the gear teeth.

Separate lubrication systems are provided for the test gears and the main gearbox. The two lubrication systems are separated at the gearbox shafts by pressurized labyrinth seals. Nitrogen is the seal gas. The test gear lubricant is filtered through a $5-\mu \mathrm{m}$-nominal fiberglass filter. The test lubricant can be heated electrically with an immersion heater. The temperature of the heater skin is controlled to prevent overheating the test lubricant.

A vibration transducer mounted on the gearbox is used to automatically shut off the test rig when a gear surface fatigue occurs. The gearbox is also automatically shut off if there is a loss of oil flow to either the main gearbox or the test gears, if the test gear oil overheats, or if there is a loss of seal gas pressurization.

The belt-driven test rig can be operated at several fixed speeds by changing pulleys. The operating speed for the tests reported herein was $10000 \mathrm{rpm}$.

\section{Test Materials}

The test gears were manufactured from consumableelectrode-vacuum-melted (CVM) AISI 9310 steel from the same heat of material. Both sets of gears were case hardened to a case hardness of Rockwell C 58 and a case depth of $0.97 \mathrm{~mm}(0.038 \mathrm{in}$.). The nominal core hardness was Rockwell C 40. One set of the gears was shot peened, after finish grinding, on the tooth root and the tooth profile according to the specifications given in table I. The chemical composition of the material is given in table II. Both sets of gears were case carburized and heat

TABLE I. - SHOT-PEENING SPECIFICATION
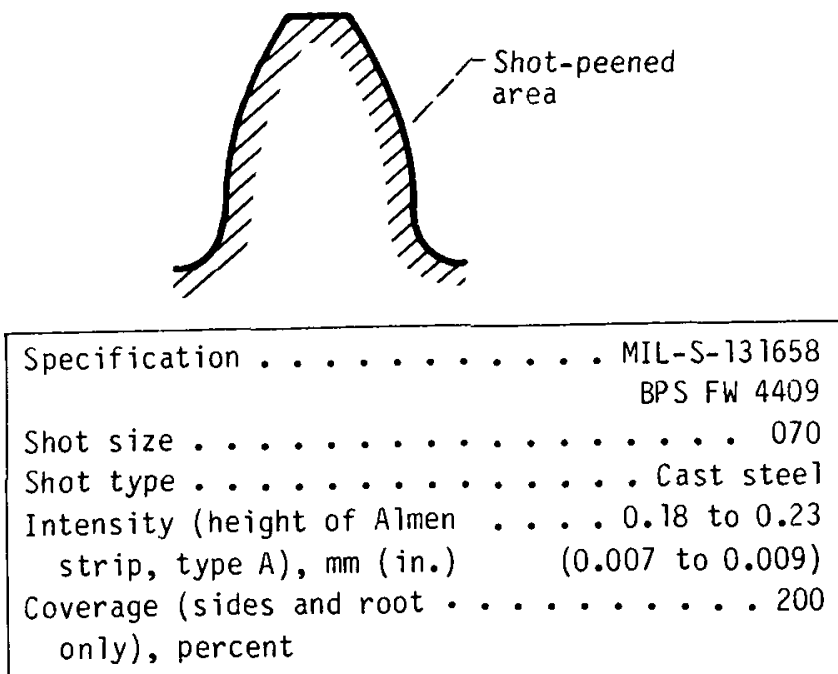

TABLE II - NOMINAL CHEMICAL

COMPOSITION OF CVM AISI

9310 GEAR MATERIAL

\begin{tabular}{|l|c|}
\hline Element & $\begin{array}{c}\text { Composition, } \\
\text { wt\% }\end{array}$ \\
\hline $\mathrm{C}$ & 0.10 \\
$\mathrm{Mn}$ & .63 \\
$\mathrm{Si}$ & .27 \\
$\mathrm{Ni}$ & 3.22 \\
$\mathrm{Cr}$ & 1.21 \\
$\mathrm{Mo}$ & .12 \\
$\mathrm{Cu}$ & .13 \\
$\mathrm{P}$ & .005 \\
$\mathrm{~S}$ & .005 \\
\hline
\end{tabular}

TABLE III. - HEAT TREATMENT FOR AISI 9310

\begin{tabular}{|c|c|c|c|c|}
\hline \multirow[t]{2}{*}{ Step } & \multirow[t]{2}{*}{ Process } & \multicolumn{2}{|c|}{ Temperature } & \multirow{2}{*}{$\begin{array}{l}\text { Time, } \\
\text { hr }\end{array}$} \\
\hline & & K & ${ }^{\circ} \mathrm{F}$ & \\
\hline 1 & Preheat in air & $-\ldots$ & $-\ldots$ & $-\cdots$ \\
\hline 2 & Carburize & 1172 & 1650 & 8 \\
\hline 3 & $\begin{array}{c}\text { Air cool to room } \\
\text { temperature }\end{array}$ & --- & --- & $-\cdots-$ \\
\hline 4 & Copper plate all over & --- & --- & $-\ldots$ \\
\hline 5 & Reheat & 922 & 1200 & 2.5 \\
\hline 6 & $\begin{array}{l}\text { Air cool to room } \\
\text { temperature }\end{array}$ & --- & --- & ---- \\
\hline 7 & Austenitize & 1117 & 1550 & 2.5 \\
\hline 8 & $0 i 1$ quench & ---- & ---- &.--- \\
\hline 9 & Subzero cool & 180 & -120 & 3.5 \\
\hline 10 & Double temper & 450 & 350 & 2 each \\
\hline 11 & Finish grind & --- & --- &.--- \\
\hline 12 & Stress retieve & 450 & 350 & 2 \\
\hline
\end{tabular}

treated in accordance with the heat treatment schedule of table III. Figure 2 is a photomicrograph of an etched and polished gear tooth surface showing the case microstructure of the AISI 9310 material.

\section{Test Gears}

Dimensions of the test gears are given in table IV. All gears have a nominal surface finish on the tooth face of $0.406 \mu \mathrm{m}(16 \mu \mathrm{in}.) \mathrm{rms}$ and a standard $20^{\circ}$ involute profile with tip relief. Tip relief was $0.0013 \mathrm{~cm}(0.0005$ in.), starting at the highest point of single-tooth contact. Surface traces of the standard gear and the shot-peened gear are shown in figure 3. 


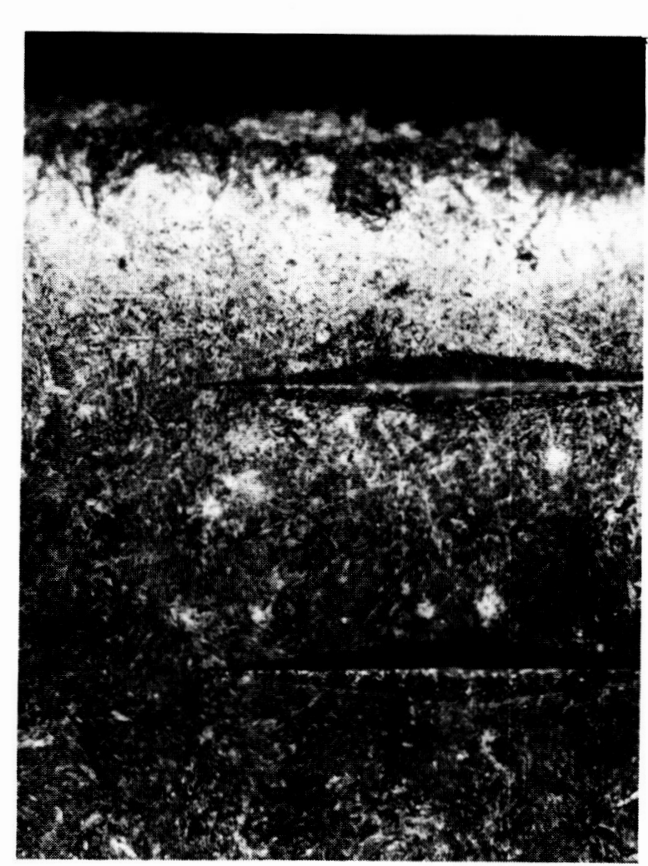

(a) Standard gear case.

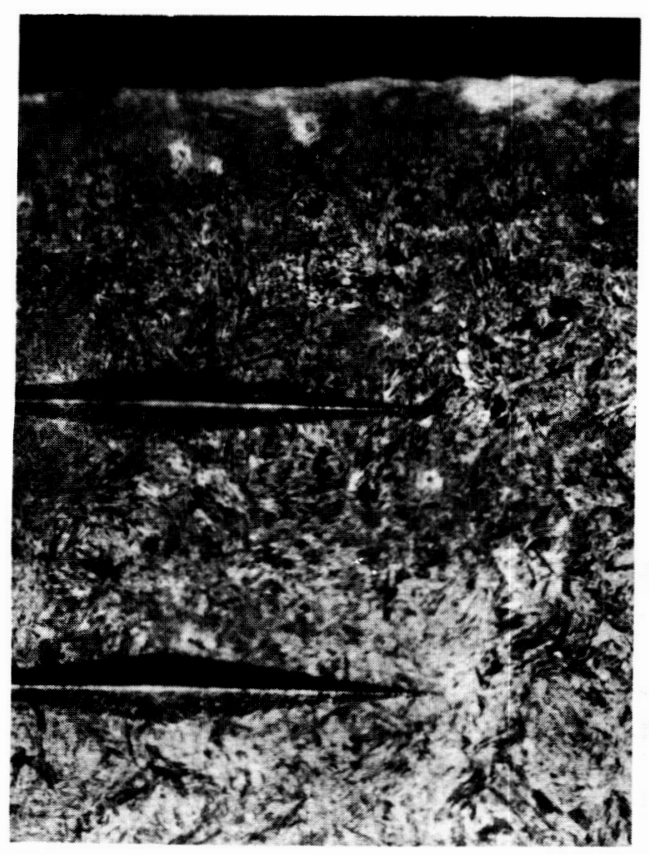

(c) Shot-peened gear case.

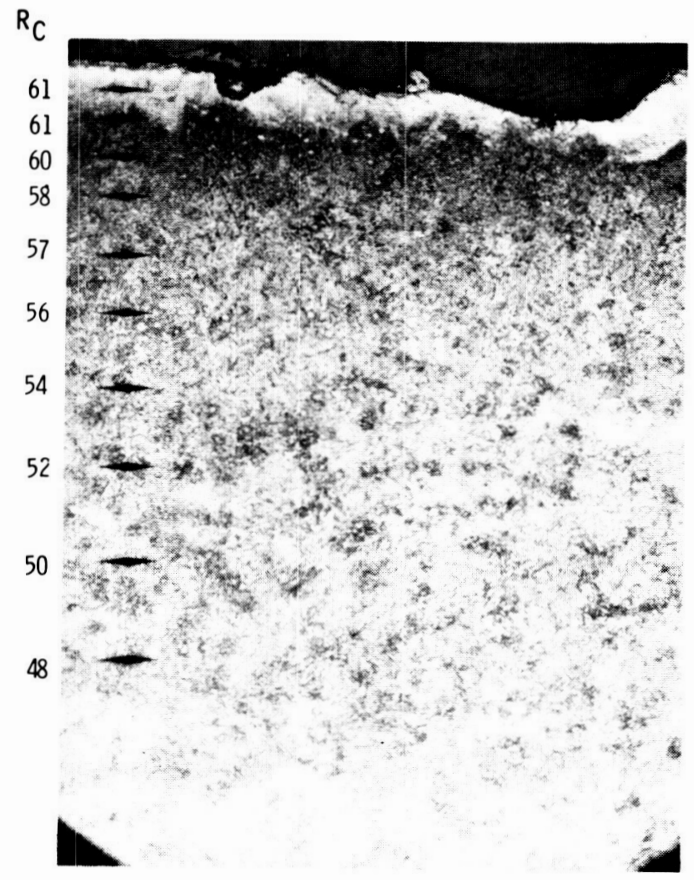

(b) Standard gear core.

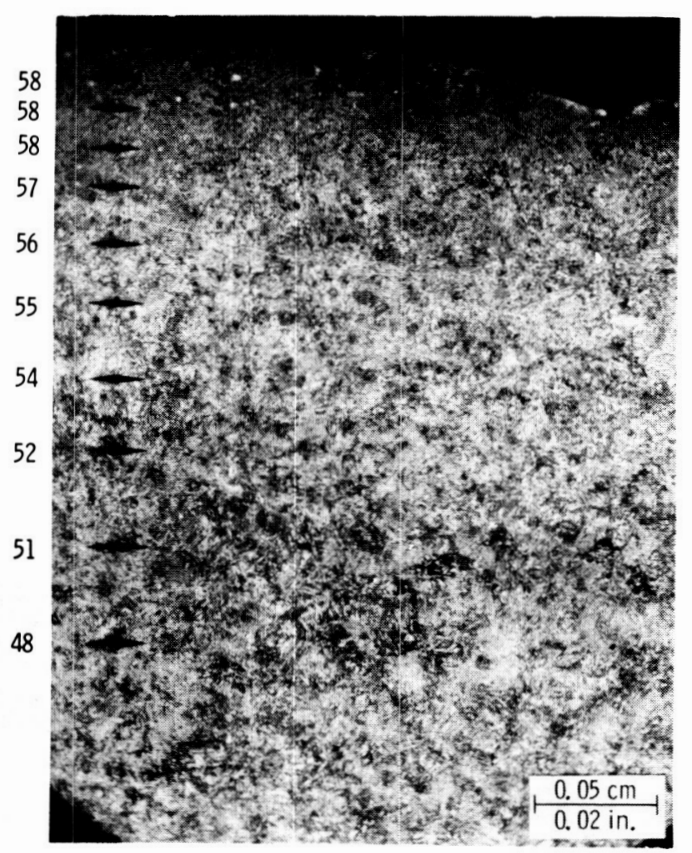

(d) Shot-peened gear core.

Figure 2. - Photomicrographs of case and core for standard and shot-peened spur gears. 
TABLE IV. - SPUR GEAR DATA

[Gear tolerance per ASMA class 12.]

\begin{tabular}{|c|c|}
\hline Number of teeth. & 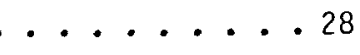 \\
\hline Diametral pitch. & - $\cdot \cdot \cdot$ \\
\hline :ular pitch, cm (in.) & - 0.997510 \\
\hline Whole depth, cm (in.) . & - 0.76210 \\
\hline Addendum, cm (in.) $\cdot$. & $\therefore 0.318 \quad(0.1$ \\
\hline $\begin{array}{l}\text { Chordal tooth thickness. } \\
\text { (reference), cm (in.) }\end{array}$ &. .0 .48510 \\
\hline Pressure angle, deg.... & $\cdot \cdot \cdot \cdot \cdot \cdot \cdot \cdot 2$ \\
\hline Pitch diameter, $\mathrm{cm}$ (in.) &.$\quad 8.890(3.500$ \\
\hline Outside diameter, cm (in.) & $\cdot .9 .525(3.7$ \\
\hline Root fillet, cm (in.) . & $\begin{array}{r}0.102 \text { to } 0 \\
(0.04 \text { to } 0\end{array}$ \\
\hline $\begin{array}{l}\text { Measurement over pins, } . \\
\mathrm{cm} \text { (in.) }\end{array}$ & $\begin{array}{l}\cdot .9 .603 \text { to } 9.630 \\
(3.7807 \text { to } 3.7915)\end{array}$ \\
\hline Pin diameter, $\mathrm{cm}$ (in.) & $\cdot .0 .549(0.2$ \\
\hline Backlash reference, $\mathrm{cm}$ (in.) & )$\cdot 0.0254(0.0$ \\
\hline Tip relief, cm (in.) . . & $\cdot 0.001$ to 0.00 \\
\hline Tooth &. $.0 .635(0.2$ \\
\hline
\end{tabular}

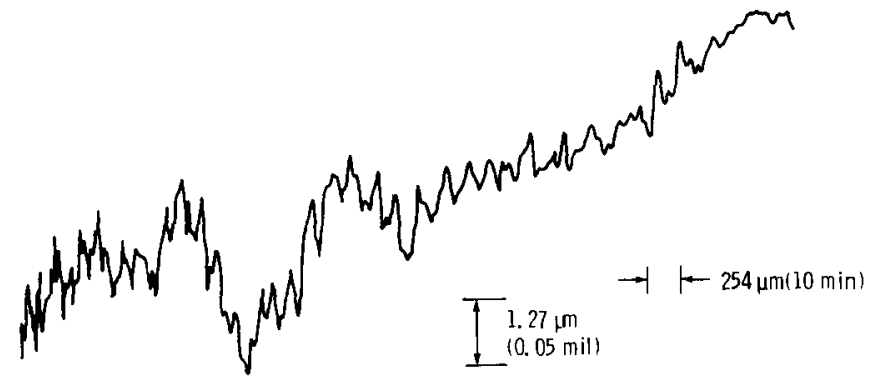

(a) Standard gear.

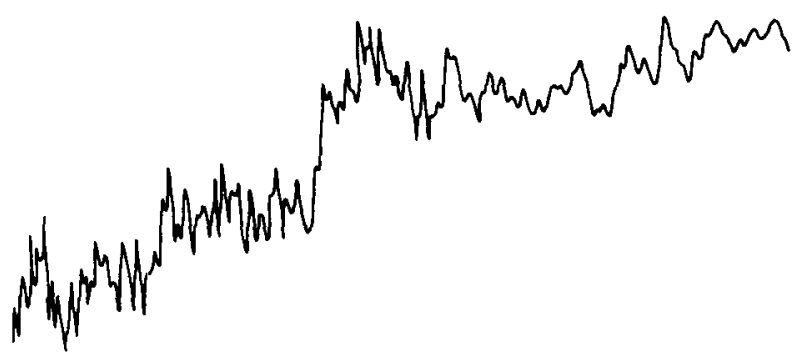

(b) Shot-peened gear.

Figure 3. - Surface finish of standard ground and shot-peened gears.

\section{Test Lubricant}

All the gears were lubricated with a single batch of synthetic paraffinic oil. The physical properties of this lubricant are summarized in table V. Five percent of an extreme-pressure additive, designated Lubrizol 5002 (partial chemical analysis given in table V), was added to the lubricant.

\section{Test Procedure}

After the test gears were cleaned to remove the preservative, they were assembled on the test rig. The 0.635 -cm $(0.25$-in.) wide test gears were run in an offset condition with a $0.30-\mathrm{cm}(0.12$-in.) tooth-surface overlap to give a load surface on the gear face of $0.28 \mathrm{~cm}$ ( 0.11 in.), thereby allowing for the edge radius of the gear teeth. If both faces of the gears were tested, four fatigue tests could be run for each set of gears. All tests were run in at a pitch-line load of $1225 \mathrm{~N} / \mathrm{cm}(700 \mathrm{lb} /$ in) for 1 hour, which gave a maximum Hertz stress of $0.756 \times 10^{9}$ $\mathrm{N} / \mathrm{m}^{2}$ (111000 psi). The load was then increased to 5784 $\mathrm{N} / \mathrm{cm}(3305 \mathrm{lb} / \mathrm{in})$, which gave a pitch-line maximum Hertz stress of $1.71 \times 10^{9} \mathrm{~N} / \mathrm{m}^{2}(248000 \mathrm{psi})$. At this pitch-line load the tooth root bending stress would be $0.21 \times 10^{9} \mathrm{~N} / \mathrm{m}^{2}(30000 \mathrm{psi})$ if plain bending were assumed. However, because there was an offset load, an additional stress was imposed on the tooth bending stress. Combining the bending and torsional moments gave a maximum stress of $0.26 \times 10^{9} \mathrm{~N} / \mathrm{m}^{2}(37000 \mathrm{psi})$. This bending stress does not include the effects of tip relief, which would also increase the bending stress.

TABLE V. - PROPERTIES OF SYNTHETIC PARAFFINIC OIL

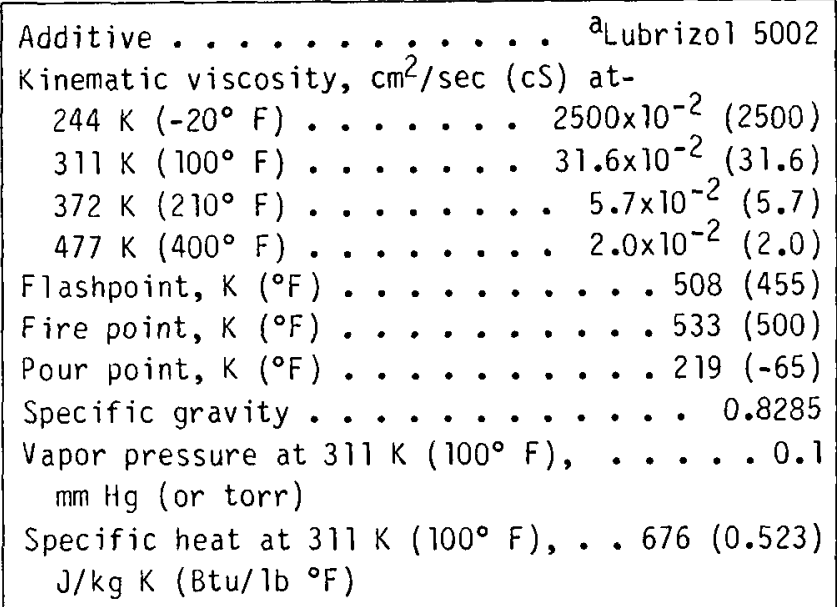

additive, Lubrizol 5002 (5 vol\%); content of additive: phosphorus, $0.6 \mathrm{wt} \%$; sulfur, $18.5 \mathrm{wt} \%$. 
Operating the test gears at $10000 \mathrm{rpm}$ gave a pitch-line velocity of $46.55 \mathrm{~m} / \mathrm{sec}(9163 \mathrm{ft} / \mathrm{min})$. Lubricant was supplied to the inlet mesh at $800 \mathrm{~cm}^{3} / \mathrm{min}$ at $319 \pm 6 \mathrm{~K}$ $\left(116^{\circ} \pm 10^{\circ} \mathrm{F}\right)$. The lubricant outlet temperature was nearly constant at $350 \pm 3 \mathrm{~K}\left(170^{\circ} \pm 5^{\circ} \mathrm{F}\right)$. The tests ran continuously $(24 \mathrm{hr} /$ day) until they were automatically shut down by the vibration detection transducer, located on the gearbox adjacent to the test gears. The lubricant circulated through a 5- $\mu \mathrm{m}$ fiberglass filter to remove w'ear particles. After each test the lubricant and the filter element were discarded. Inlet and outlet oil temperatures were continuously recorded on a strip-chart recorder

The pitch-line elastohydrodynamic (EHD) film thickness was calculated by the method of reference $t$. It was assumed, for this film thickness calculation, that the gear temperature at the pitch line was equal to the outlet oil temperature and that the inlet oil temperature to the contact zone was equal to the gear temperature, even though the inlet oil temperature was considerably lover. It is possible that the gear surface temperature was even higher than the outlet oil temperature, especially at the end points of sliding contact. The EHD film thickness for these conditions was computed to be $0.33 \mu \mathrm{m}$ (13 $\mu \mathrm{i} 11$.), which gave an initial ratio of film thickness to compo ite surface roughness $\mathrm{h} / \sigma$ of 0.55 at the $1.71 \times 10^{9}-\mathrm{N} / \mathrm{m}^{2}$ (248 000-psi) pitch-line maximum Hertz stress.

\section{Results and Discussion}

Gears manufactured from CVM AISI 9310 mate :ial were tested in pairs until failure or for 500 hours. Onehalf of the gears were shot peened on the tooth root and profile. Nineteen tests were run with standard-finish ground test gears, and 24 tests were run with standardfinish ground gears that had been shot peened. T est results were analyzed by considering the life of each pair of gears as a system.

Surface (pitting) fatigue results for the standard-finish AISI 9310 gears are shown in figure 4(a). These data were analyzed by the method of reference 7 . The 10- and 50-percent fatigue lives were $18.8 \times 10^{6}$ and $46.1 \times 106$ stress cycles ( 31.3 and $76.8 \mathrm{hr}$ ), respectively. These rest.lts are summarized in table VI. The failure index (i.e., the number of fatigue failures out of the number of sets tested) was 18 out of 18 . A typical fatigue spall is shown in figure 5(b). A cross section of a typical fatigue spal is shown in figure 5(a). The surface pitting failure occirs slightly below the pitch line in the area of highest Hettz stress and is of subsurface origin.

Pitting fatigue life results for the gears that were sh ot peened are shown in figure 4(b). The failure index was 24 out of 24. A typical fatigue spall for the shot-peened gears is shown in figure 6(a). A cross section of a typi:al fatigue spall for the shot-peened gears is shown in figure

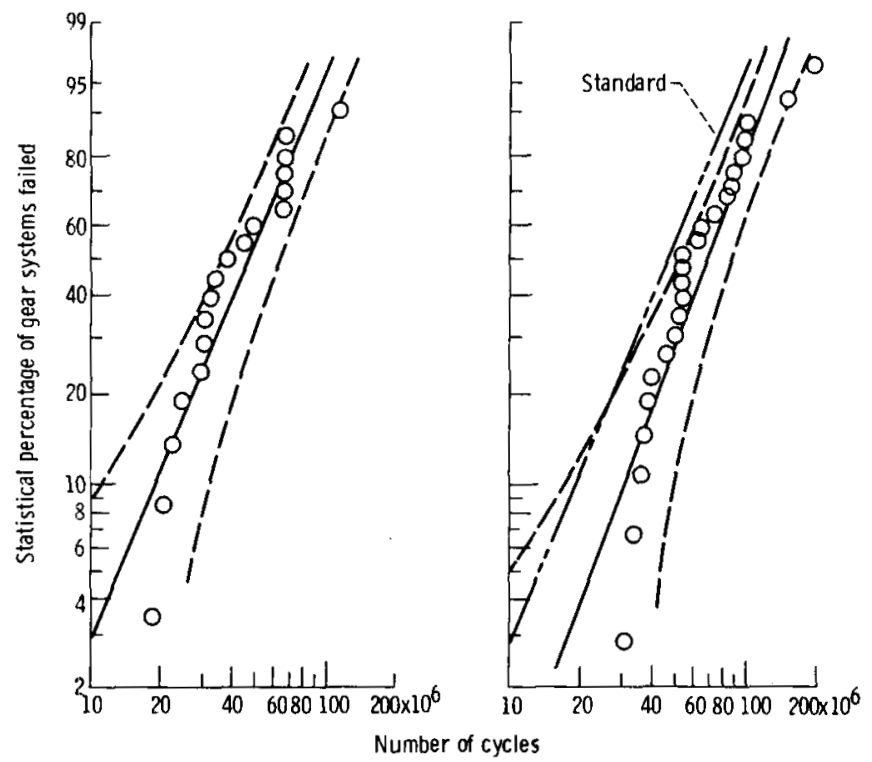

(a) Standard gears.

(b) Shot-peened gears.

Figure 4. - Comparison of surface (pitting) fatigue lives of standard ground and shot-peened carburized and hardened CVM AISI 9310 steel spur gears. Speed, $10000 \mathrm{rmm}$; lubricant, synthetic paraffinic oil; gear temperature, $350 \mathrm{~K}\left(170^{\circ} \mathrm{F}\right)$; maximum Hert stress, $1.7 \times 10^{9} \mathrm{~N} / \mathrm{m}^{2}$ (248 000 psil.

TABLE VI. - FATIGUE RESULTS WITH AISI 9310 STANDARD AND SHOT-PEENED TEST GEARS

\begin{tabular}{|l|c|c|c|c|c|}
\hline Gears & $\begin{array}{c}\text { 10-Percent } \\
\text { life, } \\
\text { cycles }\end{array}$ & $\begin{array}{c}\text { 50-Percent } \\
\text { life, } \\
\text { cycles }\end{array}$ & Slope & $\begin{array}{c}\text { Failure } \\
\text { index }\end{array}$ & $\begin{array}{c}\text { Conf idence } \\
\text { number, } \\
\text { percent }\end{array}$ \\
\hline Standard & $19 \times 10^{6}$ & $46 \times 10^{6}$ & 2.7 & $18 / 18$ & -- \\
Shot peened & 30 & 68 & 2.3 & $24 / 24$ & 83 \\
\hline
\end{tabular}

Indicates numbers of failures out of total number of tests. brobability, expressed as a percentage, that the 10-percent life with the baseline AISI 9310 gears is either less than, or greater than, that of the particular lot of gears being considered.

6(b). The 10- and 50-percent surface pitting fatigue lives were $30.1 \times 10^{6}$ and $67.5 \times 10^{6}$ stress cycles $(50.3$ and $112.6 \mathrm{hr}$ ), respectively. These results are summarized in table VI. The shot-peened gears exhibited a 10-percent fatigue life 1.6 times that of the standard ground AISI 9310 gears. The confidence number for the difference in life was 83 percent. The mean life ratio for the shotpeened over the standard AISI 9310 gears was 1.5, with a confidence number of 98 percent. The confidence number indicates the percentage of time the relative lives of the material will occur in the same order. The 90-percent confidence bands for the standard ground and shot-peened AISI 9310 test gears are shown in figure 4. A 


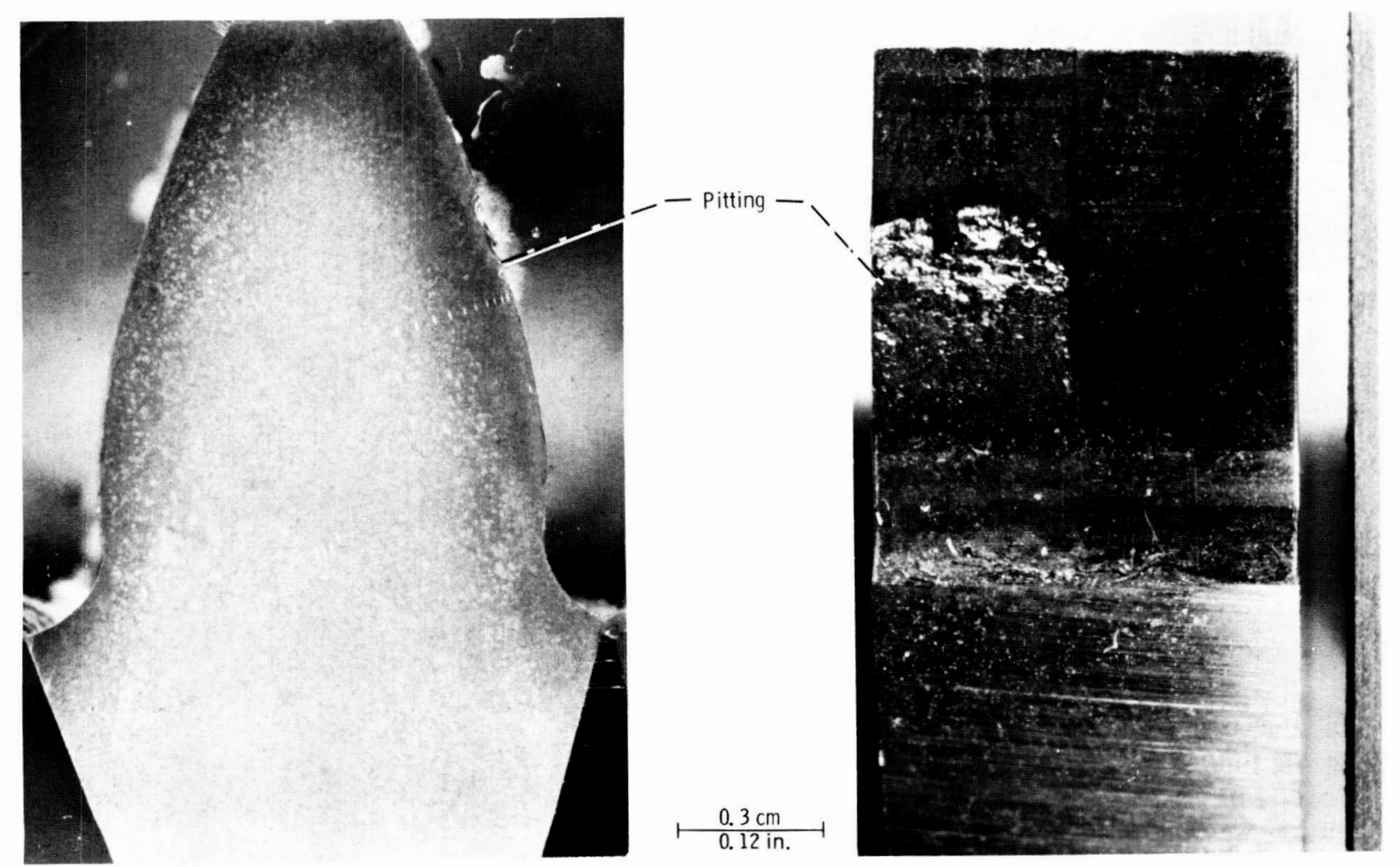

(a) Cross section of typical fatigue spall

(b) Typical fatigue spall.

Figure 5. - Fatigue spall for standard ground gear.

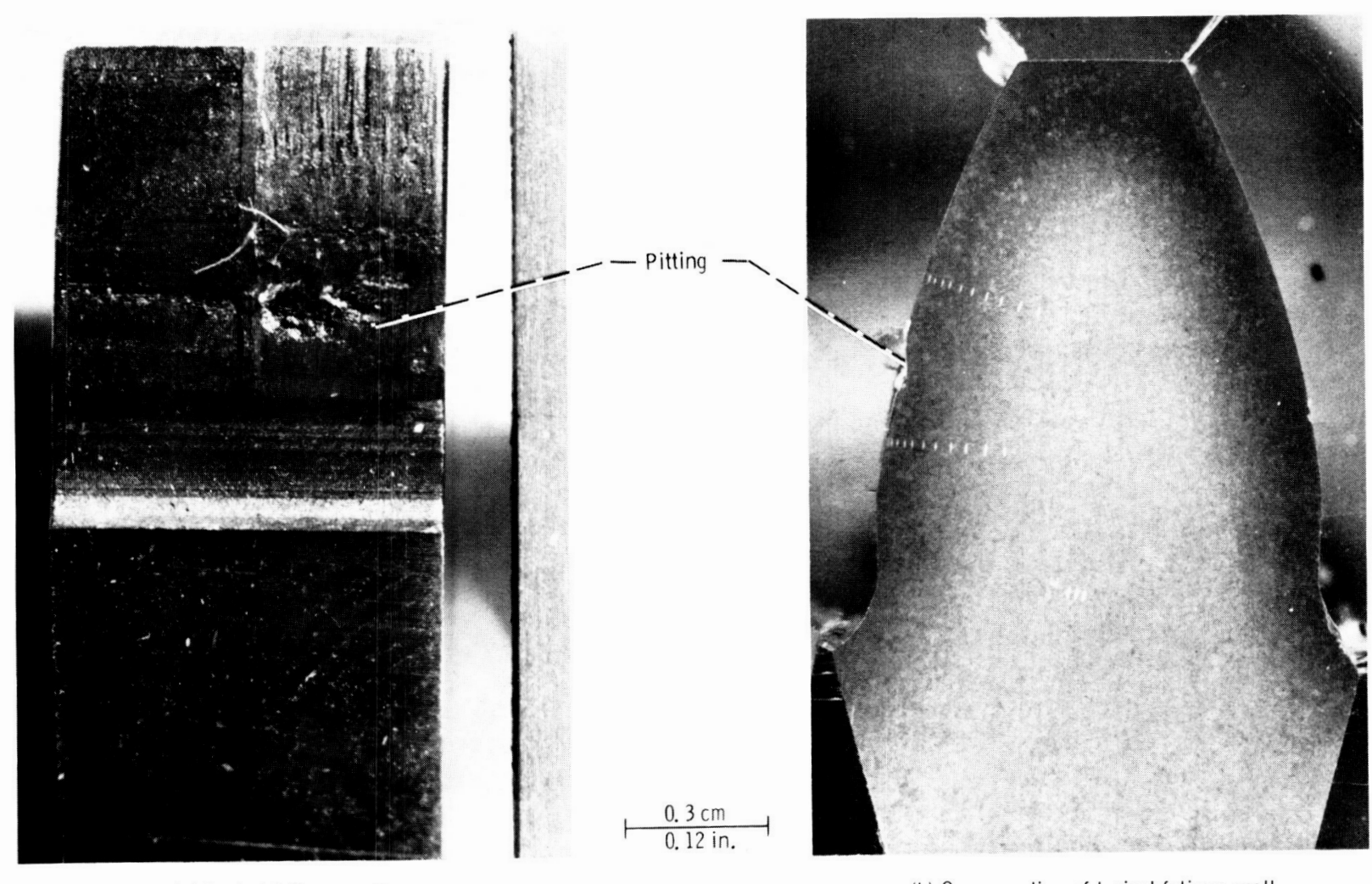

(a) Typical fatigue spall.

(b) Cross section of typical fatigue spall.

Figure 6. - Fatigue spall for shot-peened qear. 
confidence number of 95 percent is equivalent to a $2 \sigma$ confidence level.

It is well known that shot peening produces residual subsurface stresses in steel in addition to the residual stresses produced by case carburizing, hardening, and grinding. It was theorized that the additional residual stresses induced by shot peening should account for the increased life of the shot-peened gears. Therefore two shot-peened and untested gear teeth and two standard ground and untested gear teeth were subjected to $X$-ray diffraction residual stress measurements to determine the magnitude of these residual stresses. Residual stress measurements were made near the pitch point at the surface and at nominal subsurface depths of $5,13,25,76$, 127 , and $254 \mu \mathrm{m}(0.2,0.5,1.0,3,5$, and $10 \mathrm{mil})$.

Material was removed for subsurface measurement by electropolishing in a sulphuric-phosphoric-chromic acid electrolyte in order to minimize possible alteration of the subsurface residual stress distribution as a result of material removal. All data obtained as a function of depth were corrected for the effects of the penetration of the radiation employed for residual stress measurement into the subsurface stress gradient and for stress relaxation, which occurred as a result of material removal. The method used for the $\mathrm{X}$-ray stress measurements and the calibration procedures used are described in references 8 and 9 .

Figure 7 (a) shows two corrected $\mathrm{X}$-ray diffraction residual stress measurements as a function of depth below the surface for the standard ground AISI 9310 gear teeth that had not been shot peened or tested. The high compressive stress on the surface of the gear tooth is the result of grinding and has a very shallow depth that has very little effect on the surface durability of the gear. The lower compressive stress, which has much greater depth, is from the case carburizing and hardening of the gear tooth surface. This compressive residual stress has a definite beneficial effect on surface fatigue and bending fatigue life.

Figure 7(b) contains two plots of corrected X-ray diffraction residual stress measurements as a function of depth below the surface in the ground and shot-peened AISI 9310 gear teeth that had not been tested. The high grinding compressive stress on the surface was reduced. A hook in the curve shows a high compressive stress $1.3 \mu \mathrm{m}(0.5 \mathrm{mil})$ below the surface as a result of the shot peening. The compressive stress at greater depths below the surface was also increased as a result of the shot peening. It is the increased compressive stress at the greater depths that has the major effect on the surface fatigue life. The depth to the maximum shear stress for the load conditions reported herein was $178 \mu \mathrm{m}$ ( $7 \mathrm{mil})$.

Figure 7(c) contain plots of the average of the two $\mathrm{X}$-ray residual stress measurements as a function of depth below the surface for both the standard ground and shot-
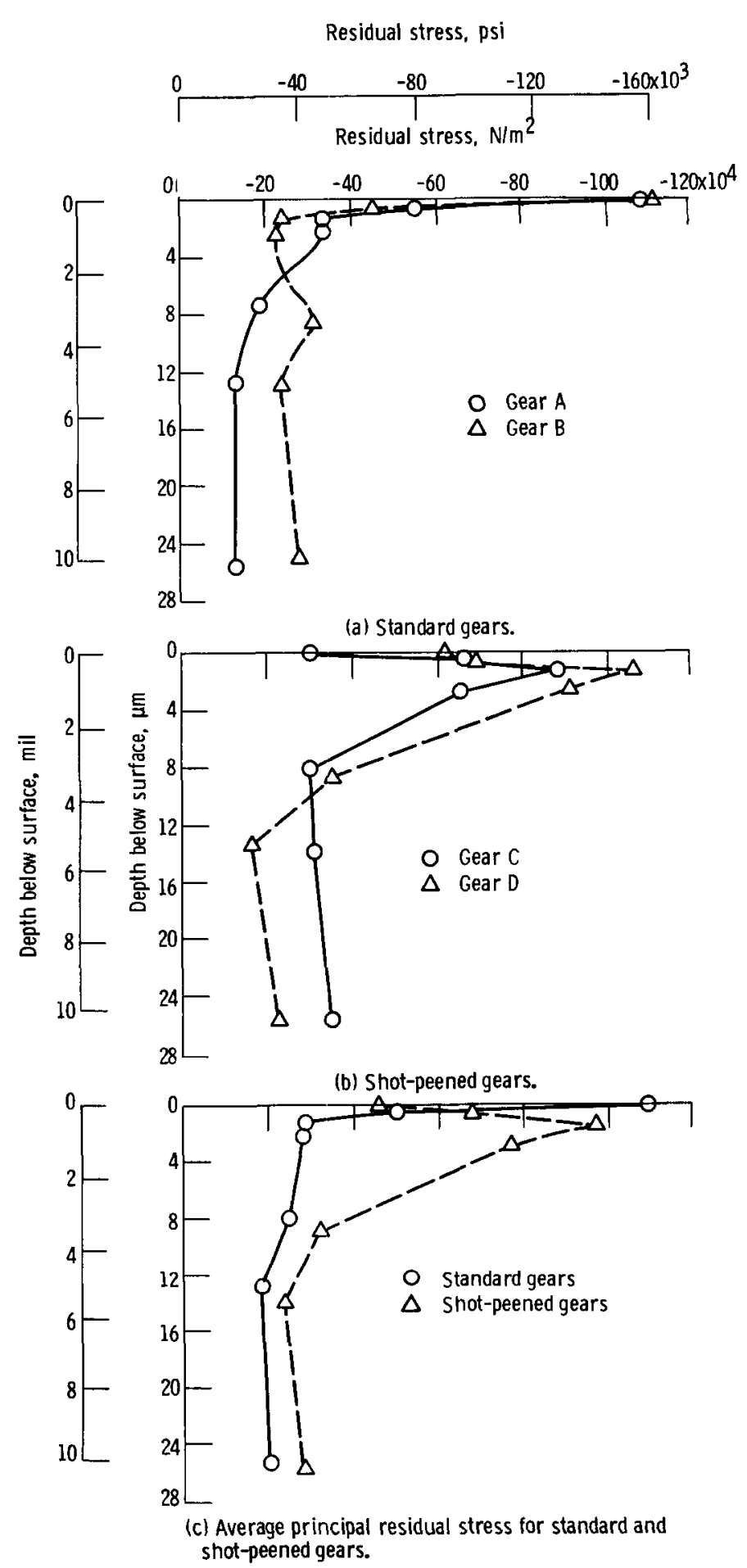

Figure 7. - Principal residual stress as a function of depth below the surface of carburized, hardened, ground and untested AISI 9310 steel spur gear teeth.

peened gears. This figure shows the average increase in the residual compressive stress due to shot peening. At the maximum shear stress depth of $178 \mu \mathrm{m}(7 \mathrm{mil})$ the average residual compressive stress was increased from $0.186 \times 10^{9} \mathrm{~N} / \mathrm{m}^{2}(27000 \mathrm{psi})$ in the standard ground 
AISI 9310 gear to $0.26 \times 10^{9} \mathrm{~N} / \mathrm{m}^{2}(37700 \mathrm{psi})$ in the ground and shot-peened AISI 9310 gear. From equation (A11), taken from the analysis given in the appendix for maximum shear stress and residual stress,

$\left(\tau_{\max }\right)_{r}=-3.15 \times 10^{6}\left(\frac{P_{N}}{L S_{\max } R}\right)-\frac{1}{2} S_{r y}$

where

$R=7.62 \mathrm{~mm}(0.3 \mathrm{in}$.

$S_{\max }=1.71 \times 10^{9} \mathrm{~N} / \mathrm{m}^{2}(248000 \mathrm{psi})$

$\frac{P_{N}}{L}=578375 \mathrm{~N} / \mathrm{m}(3305 \mathrm{lb} / \mathrm{in})$

Therefore for peened gears, in SI units,

$$
\begin{aligned}
\left(\tau_{\max }\right)_{r}=-21.74 \times 10^{9} \frac{578375}{0.00762 \times 1.71 \times 10^{9}} \\
-\frac{1}{2}\left(0.26 \times 10^{9}\right)=-0.835 \times 10^{9}
\end{aligned}
$$

in U.S. customary units,

$$
\begin{aligned}
\left(\tau_{\max }\right)_{r} & =-3.15 \times 10^{6} \frac{3305}{0.3 \times 248000}-\frac{1}{2}(-37000) \\
& =-121080
\end{aligned}
$$

And for standard gears, in SI units,

$$
\begin{aligned}
\left(\tau_{\max }\right)_{r}=-21.74 \times 10^{9} & \frac{578375}{0.00762 \times 1.71 \times 10^{9}} \\
& -\frac{1}{2}\left(0.186 \times 10^{9}\right)=-0.872 \times 10^{9}
\end{aligned}
$$

in U.S. customary units,

$$
\begin{aligned}
&\left(\tau_{\max }\right)_{r}=-3.15 \times 106 \frac{3305}{0.3 \times 248000} \\
&-\frac{1}{2}(-27000)=-126430
\end{aligned}
$$

The surface fatigue life from reference 10 for gears is inversely proportional to the maximum shear stress to the ninth power. The calculated life ratio from measured residual stress is therefore

$$
\frac{L_{10} p}{L_{10_{s}}}=\left[\frac{\left(\tau_{\max }\right)_{r s}}{\left(\tau_{\max }\right)_{r p}}\right]^{9}=\left(\frac{0.872 \times 10^{9}}{0.835 \times 10^{9}}\right)^{9}=1.5
$$

This calculated ratio of the fatigue life of the shot-peened gears to that of the standard gear compares favorably with the experimental fatigue life ratio of 1.6.

\section{Summary of Results}

Gear surface fatigue endurance tests were conducted on two groups of carburized and hardened AISI 9310 steel spur gears manufactured from the same heat of material. Both groups were manufactured with a standard ground tooth surface. One group was subjected to an additional shot-peening process on the gear tooth surface and root radius to produce a residual compressive surface stress. The gear pitch diameter was $8.89 \mathrm{~cm}$ (3.5 in.). Test conditions were a gear temperature of $350 \mathrm{~K}\left(170^{\circ} \mathrm{F}\right)$, a maximum Hertz stress of $1.71 \times 10^{9}$ $\mathrm{N} / \mathrm{m}^{2}(248000 \mathrm{psi})$, and a speed of $10000 \mathrm{rpm}$. The lubricant was a synthetic paraffinic oil with an additive package.

The following results were obtained:

1. The 10-percent surface (pitting) fatigue life of the shot-peened gears was 1.6 times that for the standard test gears that were not shot peened. This was shown to be statistically significant.

2. The calculated 10-percent surface (pitting) fatigue life for the shot-peened gears determined from measured residual subsurface stress was 1.5 times that for the standard gears that were not shot peened.

3. Measured residual stresses for the standard and shot-peened gears show an increase of 40 percent for the shot-peened gears over the standard gears at the depth of maximum shear stress in addition to a 350 percent increase at a depth of $13.0 \mu \mathrm{m}(0.5 \mathrm{mil})$.

\section{Lewis Research Center}

National Aeronautics and Space Administration Cleveland, Ohio, March 5, 1982 


\section{Appendix - Derivation of Residual Stress Effect on Maximum Shear Stress}

It is well known that classical rolling-element fatigue begins in the subsurface zone of maximum shear stress (refs. 11 and 12). Therefore, to determine the effect of residual stress on rolling-element fatigue in gears, it is necessary to analyze the effect of residual stress on the maximum shear stress below the surface. The maximum shear stress at any point in a stressed volume below a rolling line-contact load is

$\left(\tau_{\max }\right)_{y}=\frac{1}{2}\left(S_{z}-S_{y}\right)$

$\left(\tau_{\max }\right)_{x}=\frac{1}{2}\left(S_{z}-S_{x}\right)$

where $S_{z}$ is the principal compressive stress in a direction normal to the contact area, $S_{y}$ is the principal compressive stress parallel to the direction of rolling (ref. 13), and $S_{x}$ is the principal stress normal to the direction of rolling.

For rollers or gear teeth loaded statically, the maximum theoretical shear stress occurs in the $y-z$ plane since the stress in the $y$, or rolling, direction is less than the stress in the $x$ direction. Therefore the maximum shear stress is

$\tau_{\max }=\frac{1}{2}\left(S_{z}-S_{y}\right)$

If the residual stresses are equal in the $x$ and $y$ directions, for the line contact in the $y-z$ plane the maximum shear stress including the residual stress is

$\left(\tau_{\max }\right)_{r}=\frac{1}{2}\left[S_{z}-\left(S_{y}+S_{r y}\right)\right]$

$\left(\tau_{\max }\right)_{r}=t_{\max }-\frac{1}{2} S_{r y}$

where $S_{r y}$ is the residual stress in the $y$ direction and is positive for tensile stress and negative for compressive stress. From reference 13 for line contact of rollers

$\tau_{\max }=-0.30025 \frac{b}{\Lambda}$

where $b$ is the half width of the Hertzian contact,

$b=\frac{2 P_{N}}{\pi L S_{\max }}$

and $\Lambda$ for a contact of two rollers of the same material is

$\Lambda=4 \frac{R_{1} R_{2}}{R_{1}+R_{2}}\left(\frac{1-\delta^{2}}{E}\right)$

If the rollers are of the same radius,
$\Lambda=2 R\left(\frac{1-\delta^{2}}{E}\right)$

where

$P_{N} \quad$ normal load, $\mathrm{N}(\mathrm{lb})$

$S_{\text {max }}$ maximum Hertz stress, $\mathrm{N} / \mathrm{m}^{2}$ (psi)

$R_{1}, R_{2}$ radius of curvature of the two rollers, $m$ (in.)

$\delta \quad$ Poisson's ratio

$E$ Young's modulus, $\mathrm{N} / \mathrm{m}^{2}$ (psi)

Substituting equations (A6) and (A8) into equation (A5) for $\tau_{\max }$ results in

$\tau_{\max }=-0.30025 \frac{P_{N}}{\pi L S_{\max }}\left[\frac{E}{R\left(1-\delta^{2}\right)}\right]$

If equation (A9) is substituted into equation (A4),

$\left(\tau_{\max }\right)_{r}=-0.30025 \frac{P_{N}}{\pi L S_{\max }}\left[\frac{E}{R\left(1-\delta^{2}\right)}\right]-\frac{1}{2} S_{r y}$

For steel gears $E=207 \times 10^{9} \mathrm{~N} / \mathrm{m}^{2}\left(30 \times 10^{6} \mathrm{psi}\right)$ and $\delta=0.30$; therefore equation (A10) becomes for SI units

$\left(\tau_{\max }\right)_{r}=-21.74 \times 10^{9} \frac{P_{N}}{L S_{\max } R}-\frac{1}{2} S_{r y}$

and for U.S. customary units

$\left(\tau_{\max }\right)_{r}=-3.15 \times 106 \frac{P_{N}}{L S_{\max } R}-\frac{1}{2} S_{r y}$

where $S_{r y}$ can be either compressive or tensile. When gears are shot peened, the residual stress is compressive and therefore reduces the maximum shear stress.

Since the rolling-element fatigue life of gears is inversely proportional to the maximum shear stress to the ninth power (ref. 14),

$L \sim\left(\frac{1}{\tau_{\max }}\right)^{9}$

or

$L \sim\left[\frac{1}{\left(\tau_{\max }\right)_{r}}\right]^{9}$

From equation (A4), where $\left(\tau_{\max }\right)_{r}=\tau_{\max }-1 / 2\left(S_{r y}\right)$,

$L \sim\left[\frac{1}{\tau_{\max }-1 / 2\left(S_{r y}\right)}\right]^{9}$

using a life ratio of $L_{1}$ and $L_{2}$ 


$$
\frac{L_{1}}{L_{2}}=\left[\frac{\tau_{\max }-1 / 2\left(S_{r y}\right)_{2}}{\tau_{\max }-1 / 2\left(S_{r y}\right)_{1}}\right]^{9}
$$

When the residual stress developed by the shot peening of the gear teeth is known, the change in life produced by shot peening can be determined from equation (A14). 


\section{References}

1. Moore, H. F.: Shot Peening and the Fatigue of Metals. American Foundry Equipment Co., 1944.

2. Straub, J. C.: Shot Peening in Gear Design. AGMA Paper 109.13, June 1964.

3. Valentine, K. B.: Recrystallization as a Measurement of Relative Shot Peening Intensities. Am. Soc. Met. Trans. Q., vol. 40, 1948, pp. 420-434.

4. Zaretsky, Erwin V.; et al.: Effects of Component Differential Hardness on Residual Stress and Rolling-Contact Fatigue. NASA TN D-2664, 1965.

5. Zaretsky, E. V.; Parker, R. J.; and Anderson, W. J: Component Hardness Differences and Their Effect on Bearing Fatigue. J. Lub. Technol,, vol. 89, no. 1, Jan. 1967, pp. 47-62.

6. Dowson, D.; and Higginson, G. R.: Elasto-Hydrodynamic Lubrication. Pergamon Press, 1966, p. 96.

7. Johnson, Leonard G.: The Statistical Treatment of Fatigue Experiments. Elsevier Pub. Co., 1964.

8. Christenson, A. L., ed.: Measurement of Stress by X-Ray. SAE HS-182, Aug. 1971.
9. Prevey, Paul S.: Method of Determining the Elastic Properties of Alloys in Selected Crystallographic Directions for X-Ray Defraction Residual Stress Measurements. Adv. X-Ray Anal., vol. 20, 1977, pp. 345-354.

10. Townsend, D. P.; Coy, J. J.; and Zaretsky, E. V.: Experimental and Analytical Load Life Relation for AISI 9310 Steel Spur Gears. Journal of Mechanical Design, Trans. ASME, vol. 100, no. 1, Jan. 1978, pp. 54-60.

11. Jones, A. B.: Metallographic Observations of Ball Bearing Fatigue Phenomena. Symposium on Testing of Bearings, ASTM, 1947, pp. 35-48; discussion, pp. 49-52.

12. Carter, T. L.; et al.: Investigation of Factors Governing Fatigue Life with the Rolling-Contact Fatigue Spin Rig. Am. Soc. Lubr. Eng. Trans., vol. 1, no. 1, Apr. 1958, pp. 23-32.

13. Jones, A. B.: New Departure-Analysis of Stress and Deflections. Vol. I, New Departure, Div. Gen. Motors Corp., 1946, p. 22.

14. Lundberg, G.; and Palmgren, A.: Dynamic Capacity of Rolling Bearings. Acta. Polytech. Scand., Mech. Eng. Ser., vol. 1, no. 3, 1947. 


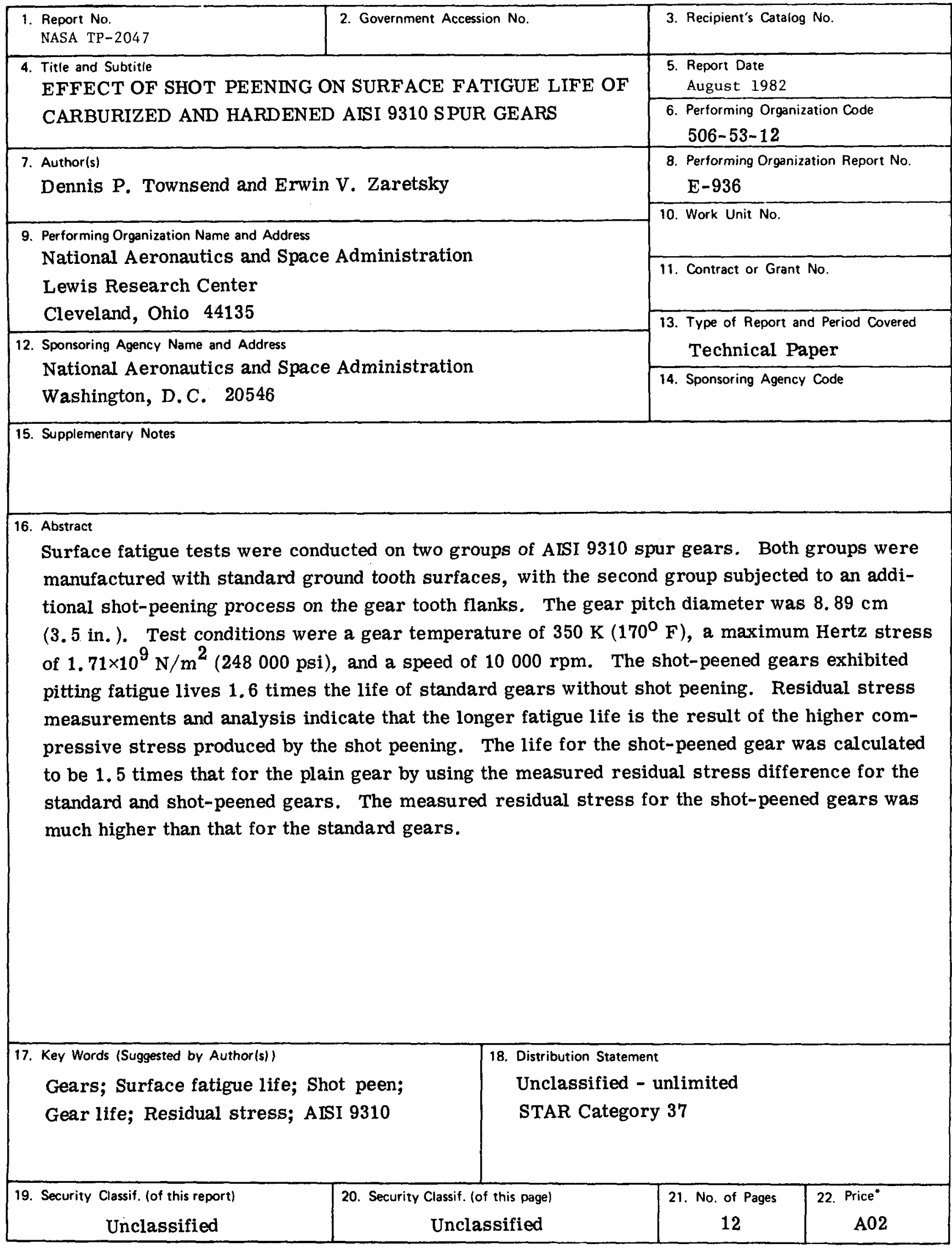

